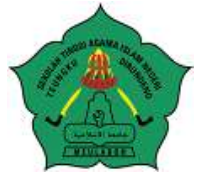

AT-TASYRI' Jurnal Ilmiah Prodi Muamalah

P-ISSN: 2085-2541, E-ISSN: 2715-7865

Volume 12, Nomor 1, Juni 2020

https://ejournal.staindirundeng.ac.id/index.php/Tasyri

\title{
DAMPAK LABEL SYARIAH TERHADAP PENDAPATAN PADA USAHA JASA DI KOTA LANGSA (Studi Kasus Pada Amanah Wash Laundry Syariah)
}

\author{
Nurjanah \\ Dosen Fakultas Ekonomi dan Bisnis Islam IAIN Langsa \\ nurjannah@iainlangsa.ac.id \\ Rafiza Zuliani \\ Fakultas ekonomi dan bisnis Islam IAIN Langsa \\ rafizuli@gmail.com
}

\begin{abstract}
Abstrak
Saat ini banyak sekali usaha home industri seperti penatu yang memakai konsep syariah. Tulisan ini hendak mengkaji salah satu usaha penatu yang menggunakan konsep syariah di kota langsa. Penelitian ini bertujuan untuk melihat dampak label syariah terhadapat pendapatan pada Amanah Wash Laundry Syariah Laundry. Metode yang digunakan adalah analisis kualitatif dengan teknik komparasi dan interaktif. Hasil penelitian menunjukkan bahwa dampak label syariah terhadap pendapatan amanah wash syariah laundry berpengaruh namun tidak secara signifikan karena beberapa pelanggan menggunakan jasa laundry berdasarkan logika, kualitas pelayanan, lokasi dan lain-lain. Kemudian, aplikasi prinsip thaharah pada pencucian pakaian di amanah wash syariah laundry sudah sesuai. Pendapatan dari maret ke april mengalami kenaikan sebesar $4.47 \%$, hal ini dikarenakan masih hanya orang-orang yang sama yang menjadi pelanggan amanah wash syariah laundry dan pelanggan mengajak teman atau saudara dari pelanggan untuk menggunakan jasa amanah wash syariah laundry.
\end{abstract}

Kata Kunci: Laundry, Pendapatan, Label Syariah

\begin{abstract}
At present there are a lot of home business industries such as cleaners who use the concept of sharia. This paper would like to examine one of the laundry business that uses the concept of sharia in the city of Langsa. This study aims to look at the impact of sharia labels on income on the Laundry Laundry Laundry Amanah Amanah. The method used is qualitative analysis with comparative and interactive techniques. The results showed that the impact of sharia labels on washing shariah laundry trust income influences but not significantly because some customers use laundry services based on logic, service quality, location, and others. Then, the application of the thaharah principle to washing clothes in the Islamic Shariah laundry trust is appropriate. Revenue from March to April increased by $4.47 \%$, this is because there are still only the same people who are customers of the Shariah Laundry Trust Trust and customers inviting friends or relatives of customers to use the Shariah Laundry Trust Trust Service.
\end{abstract}

Keywords: Laundry, Income, Sharia Label 


\section{A. PENDAHULUAN}

Perkembangan label "syariah" di Indonesia banyak bermunculan dan menjadi trend masyarakat Indonesia di berbagai bidang, baik usaha produk, jasa, perbankan dan hiburan. Seperti hotel syariah, perbankan syariah, dan juga laundry syariah. Ada beberapa faktor yang harus diperhatikan oleh dunia usaha agar konsumen tertarik, salah satunya adalah aspek pelayanan yang diberikan kepada konsumen. Selain sisi pelayanan, setiap usaha baik yang berupa barang atau jasa, jika ingin dikenal oleh konsumen, sangatlah perlu dipertimbangkan sebuah nama atau brand.

Salah satu usaha jasa yang dilirik oleh investor yakni usaha laundry atau pencucian pakaian. merupakan salah satu jenis usaha yang saat ini banyak berkembangan dan bertebaran di tengah-tengah masyarakat khususnya daerah perkotaan. Hal ini dikarenakan mayoritas masyarakat perkotaan disibukkan dengan sistem kerja atau rutinitas yang tidak ada waktu untuk mencuci pakaian.

Kelebihan dari jasa laundry selain harganya yang bersaing, hasil cucian yang bersih juga menjadi sebab lirikan konsumen. Salah satu laundry yang memberikan jasa pencucian bersih dan wangi sesuai syariah adalah amanah wash syariah laundry. Usaha laundry syariah ini memberikan daya tarik tersendiri bagi kalangan masyarakat. Usaha ini bisa jadi pilihan bagi para pelaku bisnis pemula, karena Indonesia sebagian besar penduduknya memeluk agama Islam. Aceh merupakan daerah yang mayoritas beragama Islam yang taat, sehingga dalam menjalankan aktivitas kesehariannya akan berkaitan erat dengan hal-hal yang dianjurkan ajaran Islam. Salah satunya bagaimana menyucikan najis dari pakaian, dengan demikian hadirnya usaha laundry syariah akan sangat membantu bagi keluarga atau individu yang aktivitas kesehariannya di luar rumah, sehingga mereka menggunakan jasa laundry yang ditawarkan.

Amanah wash merupakan laundry syariah pertama yang hadir di kota Langsa yang menggunakan konsep thaharah, dimana konsep thaharah disini mencakup dua hal, yaitu: thaharah zhahir dan batin. Thaharah zhahir sendiri adalah amanah wash menawarkan dapat menyucikan pakaian sesuai dengan ajaran Islam, yakni hilang warna, bau, dan rasa nya. Kemudian thaharah batin disini terdapat pada batin pengelola dan pekerja di amanah wash, yang memiliki sifatsifat amanah, siddiq, tabligh. Amanah dalam arti pihak amanah wash melayani konsumen sesuai dengan permintaan konsumen, seperti seorang konsumen tidak ingin memakai pewangi/parfum pada pakaiannya karena berkeyakinan bahwa alkohol tidak dapat digunakan untuk ibadah shalat. Sifat siddiq atau jujur dalam bekerja dan tabligh adalah menyampaikan jika sesuatu yang tidak diingankan terjadi dari barang konsumen, seperti hilang, luntur, dan cacat.

Awal munculnya usaha amanah wash berawal dari minimnya jasa laundry yang menawarkan jasa mencuci pakaian yang berdasarkan sayariat Islam. Beberapa laundry tidak mengetahui bagaimana menjadikan pakaian suci lagi menyucikan, kebanyakan laundry yang ada hanya membersihkan pakaian ala kadarnya, karena bersih belum tentu suci, namun suci sudah pasti bersih. Dan masih banyak pengguna jasa laundry yang kurang peduli terhadap kebersihan najis yang masih melekat pada pakaiannya, dan tetap digunakan untuk menjalankan ibadah salat seperti yang terjadi pada beberapa laundrylaundry yang berada di Yogyakarta. ${ }^{1}$

\footnotetext{
${ }^{1}$ Widyarini, Pemanfaatan Peluang Bisnis Laundry Syariah. Jurnal Ekonomi dan Bisnis Islam, Vol. XI, No. 1, Desember 2015. hal. 55.
} 
Amanah wash berdiri mulai akhir bulan Januari tahun 2017 namun konsumen yang menggunakan jasanya selama dua bulan telah mencapai 150 orang. Hal ini menandakan adanya antusias dari masyarakat kota Langsa terhadap produk usaha laundry syariah ini terbilang sangat baik. Konsumen amanah wash sebagian besar mengetahui keberadaan laundry syariah ini dari rekomendasi temannya. Ada juga seorang konsumen yang memang sengaja mencari jasa laundry yang berbasis syariah, hal ini dikarenakan istrinya yang baru saja melahirkan mengkhawatirkan kesucian pakaiannya jika diberikan ke jasa laundry biasa. ${ }^{2}$

Berbeda dengan laundry syariah dalam proses laundry secara syariah yang terutama adalah di tahap mensucikan apa yang akan dicuci, pada tahap ini cucian dipilah dan disucikan terlebih dahulu satu per satu dengan menggunakan air mengalir. Proses mencuci yang ditawarkan pada amanah laundry terdapat dua cara, pertama menggunakan tangan dan kedua menggunakan mesin. Pakaian bernajis seperti pakaian yang terkena kotoran akan dipisahkan terlebih dahulu dan dihiangkan bau, rasa dan warnanya. Dengan demikian, akan membuat masyarakat menjadi lebih tenang saat melakukan ibadah karena pakaian telah suci lagi menyucikan. Peluang usaha laundry syariah saat ini berkembang pesat dan memiliki sistem kemajuan yang tinggi karena asas yang diterapkan sesuai dengan ajaran agama islam dan proses yang dijalankan sangat profesional dan terjamin kualitas hasil cucian. Dengan demikian, maka penelitian ini akan mengangkat judul tentang "Dampak label syariah terhadap pendapatan pada usaha jasa di kota langsa (studi perbandingan pada amanah wash syariah laundry).

\section{B. KAJIAN PUSTAKA}

Penelitian yang dilakukan oleh Widyarini yang berjudul 'Pemanfaatan Peluang Bisnis Laundry Syariah", penelitian ini dilakukan di beberapa jasa laundry yang ada di Yogyakarta. Hasil penelitiannya mengatakan bahwa masih banyak penjual jasa laundry yang tidak memiliki wawasan cara mencuci dari kotoran dan najis secara benar untuk pakaian muslim, masih banyak pengguna jasa laundry yang kurang peduli terhadap kebersihan najis yang masih melekat pada pakaiannya, dan tetap digunakan untuk menjalankan ibadah salat. Dengan demikian, bisnis laundry syariah masih memiliki peluang yang menarik untuk ditekuni. ${ }^{3}$

"Faktor-faktor yang mendasari konsumen dalam memilih hotel syariah walisongo" terdapat empat faktor yaitu : faktor budaya, faktor sosial, faktor psikologis, dan faktor pribadi. Dari faktor tersebut yang mempengaruhi konsumen dalam memilih hotel syariah adalah faktor budaya, yang meliputi: faktor lokasi, pelayanan dan fasilitas. Faktor lain yang mempengaruhi konsumen adalah faktor sosial karena bersama kelompok atau keluarganya. Sedangkan faktor psikologis dan faktor pribadi tidak memiliki pengaruh yang besar terhadap konsumen dalam meilih hotel syariah. $^{4}$

Penelitian Nurul Huda dan Muchlisin "Pengaruh Label Halal Pada Makanan Terhadap Konsumsi Mahasiswa Fakultas Agama Islam Universitas Muhammadiyah surakarta”. Hasilnya mengatakan bahwa dapat

\footnotetext{
${ }^{2}$ Wawancara dengan owner amanah wash, ibu Masyitah.

${ }^{3}$ Widyarini, Pemanfaatan Peluang Bisnis Laundry Syariah. Jurnal Ekonomi dan Bisnis Islam, Vol. XI, No. 1, Desember 2015. hal. 55.

${ }^{4}$ Saiful Bahri, Faktor-Faktor Yang Mendasari Konsumen Dalam Memilih Hotel Syariah Walisongo. Skripsi, UIN Sunan Ampel, 2015.
} 
diklasifikasikan dalam tiga kelompok: pertama, mereka yang memperhatikan label halal produk makanan yang akan dikonsumsi. Kedua, mereka tidak memperhatikan label halal produk makanan yang akan dikonsumsi. Ketiga, mereka kadang-kadang memperhatikan label halal produk makanan yang akan dikonsumsi. ${ }^{5}$

Selain itu Brilyan Rahmat Sukmono juga melakukan penelitian yang berjudul "Pengaruh Label "Syariah" Pada Lembaga Perbankan Terhadap Jumlah Nasabah BNI Syariah Cabang Jakarta Selatan”. Hasil penelitiannya mengungkapkan bahwa respon nasabah terhadap label atau brand syariah positif dan signifikan. Hal ini terbukti dari jumlah nasabah yang meningkat signifikan setiap tahunnya dari 2006 berjumlah 9.491 nasabah sampai desember 2010 menjadi 33.798 nasabah. ${ }^{6}$

Maya Anggraeini meneliti tentang "Pengaruh Persepsi Label Halal, Citra Merek (Brand Image), dan word of mouth (WOM) Terhadap Minat Beli Ulang Produk (Studi Kasus Pada Restoran Solaria Ambarukmo Plaza Yogyakarta)". Mengatakan bahwa persepsi halal berpengaruh positif dan signifikan terhadap minat beli ulang produk dengan nilai regresi 0,166 dan tingkat signifikansinya 0,046 , citra merek berpengaruh positif namun tidak signifikan dengan nilai regresi 0,091 dan tingkat signifikansinya 0,136 , word of word berpengaruh secara positif dan signifikan dengan nilai regresi 0,801 dan tingkat signifikansinya $0,000 .^{7}$

Wahyu Budi Utami juga meneliti tentang "Pengaruh label halal terhadap keputusan membeli (survei pada pembeli produk kosmetik wardah di outlet wardah griya muslim an-nisa yogyakarta). Dimana hasil penelitian menunjukkan bahawa label halal yang terdapat pada kemasan produk kosmetik wardah mempunyai hubungan yang signifikan terhadap keputusan membeli, ditunjukkan dengan nilai sebesar $0,666>\mathrm{r}$ tabel $(0,207)^{8}$

Penelitian yang dilakukan oleh "pengaruh biaya promosi terhadap pendapatan O Laundry" hasil penelitian ini menyatakan bahwa hasil keseluruhan regresi adalah $\mathrm{Y}=2566053+0.75555 \mathrm{X}$, selain itu didapat juga koefisien determinasinya (R) keseluruhannya sebesar $0.2 \%$, yang berarti bahwa biaya promosi tidak berpengaruh terhadap tingkat pendapatan. ${ }^{9}$

Penelitian yang dilakukan oleh Osin Tompodung "Analisis Net Profit Margin Pada Usaha Laundry di Kota Manado" tujuan dari penelitian ini adalah untuk menganalisis NPM pada usaha laundry di manado yaitu di Henny laundry, revina laundry, dan Nila clean laundry. Metode penelitian yang digunakan adalah metode deskripsi kuantiitatif. Objek yang penelitian ini adalah ketiga usaha laundry tersebut dan data yang dianalisis merupakan data keuangan dari ketiga laundry tersebut. Hasil penelitian ini menunjukkan bahwa NPM Henny laundry mengalami trend

\footnotetext{
${ }^{5}$ Nurul Huda dan Muchlisin, Pengaruh Label Halal Pada Makanan Terhadap Konsumsi Mahasiswa Fakultas Agama Islam Universitas Muhammadiyah surakarta. Suhuf, Vol.26, No.1, Mei 2014: hal. 57-66

${ }^{6}$ Brilyan Rahmat Sukmono, Pengaruh Label "Syariah” Pada Lembaga Perbankan Terhadap Jumlah Nasabah BNI Syariah Cabang Jakarta Selatan. Skripsi. UIN Syarif Hidayatullah.

${ }^{7}$ Maya Anggraeini, Pengaruh Persepsi Label Halal, Citra Merek (Brand Image), dan word of mouth (WOM) Terhadap Minat Beli Ulang Produk (Studi Kasus Pada Restoran Solaria Ambarukmo Plaza Yogyakarta). Skripsi Universitas Negeri Yogyakarta, 2016.

${ }^{8}$ Wahyu Budi Utami, Pengaruh label halal terhadap keputusan membeli (survei pada pembeli produk kosmetik wardah di outlet wardah griya muslim an-nisa yogyakarta). Skripsi UIN Sunan Kalijaga, 2013.

${ }^{9}$ Fam Thusitha Dharmapala, Pengaruh Biaya Promosi terhadap Peningkatan Pendapatan O’laundry Bandung. Skripsi, Universitas Kristen Maranatha, 2016.
} 
kenaikan pada tahun 2013. NPM untuk Nila clean laundry di tahun yang sama cenderung stabil. NPM untuk revina laundry mengalami trens kenaikan di tahun 2013 dan Henny laundry memiliki nilai NPM tertinggi dibandingkan kedua usah alaundry lainnya. Sebaiknya pihak manajemen Henny laundry mempertahankan tingkat pendapatan untuk menjaga NPM tetap baik. Sebaliknya pihak manajemen Revina laundry meningkatkan pendapatan usaha sehingga NPM dapat meningkat. ${ }^{10}$

Pengaruh Promosi Terhadap Tingkat Penjualan Clean Up Laundry Bogor oleh Anzani Rakhmawati Santika. Tujuan dari penelitian ini adalah untuk mengetahui bentuk promosi yang dilakukan oleh clena up laundry, kegiatan promosi apa saja yang dilakukan oleh clean up laundry, dan menganalisis pengaruh kegiatan promosi terhadap tingkat pengjualan pada clean up laundry. Hasil penelitian yang diperoleh selama tahun 2007 sampai tahun 2011 kegiatan promosi yang dilaksanakan cleap up laundry hanya sebatas pada periklanan, promosi penjualan dan pemasan langsung. Untuk kegiatan promosi penjualannya clean up laundry lebih kepada adanya diskon dan program paket. Hal tersebut dimaksudkan agar konsumen yang memakai jasa clean up laundry tetap loyal terhadap jasa yang sudah diberikan sehingga dapat meningkatkan penjualan. Pada pemasaran langsung lebih memfokuskan kepada penyebaran brosur dan menyebarkan lewat e-mail kepada konsumen. ${ }^{11}$

Analisis Strategi Pemasaran Dalam Upaya Meningkatkan Pendapatan Petani
Dalam Perpektif Ekonomi Islam (Studi Pada Petani Buah Naga Di Desa Sri Pendowo Kecamatan Bangunrejo Kabupaten Lampung Tengah) oleh Umi Sa'dah. Penelitian ini merupakan penelitian field research digunakan dengan cara menggali data yang bersumber dari lokasi penelitian lapangan. Penelitian ini bersifat deskripsi kualitatif yaitu penelitian yang bersifat memaparkan dan bertujuan untuk memperoleh gambaran yang lengkap tentang sesuatu yang sedang diteliti. Teknik pengumpulan data yang digunakan adalah observasi, wawancara dan dokumentasi. Hasil penelitian bahwa strategi pemasaran yang diterapkan dalam meningkatkan pendapatan petani adalah dengan menerapkan system bauran pemasaran: product, price, place dan promotion. Dari strategi yang diterapkan, pendapatan petani buah naga mengalami penigkatan yang cukup signifikan, yaitu pendapatan pada tahun 2013 sebanyak 200,708-ton dengan luas areal 17 hektar, pada tahun 2014 mencapai 212,314-ton dengan luas areal 17 hektar, pada tahun 20144 mencapai dengan luas areal 20 hektar dan mencapai 235,525 pada tahun 2016 dengan luas areal 25 hektar. ${ }^{12}$

Penelitian rahmat setiawan, yang berjudul "Perancangan Jasa Layanan Baru di DJAPA Laundry" Metode yang digunakan dalam penelitian ini adalah metode SERVQUAL, yang mengidentifikasikan kualitas pelayanan ke dalam 5 dimensi, yaitu tangible, reliability, responsiveness, emphathy dan assurance. Pengukuran DEA menghitung layanan baru yang sudah dibuat. Dan menghitung kelayakan bisnis, dimana

\footnotetext{
${ }^{10}$ Osin Tompodung, Analisis Net Profit Margin Pada Usaha Laundry di Kota Manado. Jurnal EMBA, Vol. 2 No. 2 Juni 2014, hal. 1682

${ }^{11}$ Anzani Rakhmawati Santika, Pengaruh Promosi Terhadap Tingkat Penjualan Cllean Up Laundry Bogor. Skripsi, institut pertanian bogor, 2012.

${ }^{12}$ Umi Sa'dah, Analisis strategi pemasaran dalam upaya meningkatkan pendapatan petani dalam perpektif ekonomi islam (studi pada petani buah naga di desa sri pendowo kecamatan bangunrejo kabupaten lampung tengah), skripsi, Universitas Islam Negeri Raden Intan, 2017.
} 
layak atau tidaknya layanan baru tersebut untuk direalisasikan. Hasil penelitian ini menunkukkan bahwa dari 15 layanan baru yang sudah dibuat, ada 8 layanan yang layak untuk direalisasikan. Dimana usulan perbaikan yang ditawarkan untuk meningkatkan pendapatan perusahaan Djapa Laundry yaitu dengan menambahkan, membuat dan merealisasikan 8 layanan baru yang sudah dihitung nilai efisiensinya dan sudah dihitung kelayakan bisnisnya. ${ }^{13}$

"Pengembangan laundry kiloan pada indie laundry dengan sistem outlet apartemen" oleh andriyanto wibowo. Tujuan penelitian adalah mengetahui kelayakandari pengembangan bisnis yang akan dilakukan dengan membuka sistem outlet di apartemen, mengetahui faktor-faktor apa saja yang akan mempengaruhi pedapatan usaha outlet laundry di apartemen. Instrumen yang digunakan untuk membuat analisis profitabilitas bisnis ini adalah analisis SWOT dan analisis proyeksi laporan keuangan, maka diperoleh BEP adalah sebesar Rp. 110.800.000, hasil NPV menghasilkan nilai positif sebesar 427.237.059., perhitungan payback period dicapai setelah 12 bulan, perthitungan IRR sebesar 59,36916\%, perhitungan profitabiltay index sebesar 2.5 serta sensitivitas analisis memberikan perhitungan penurunan maksismal yang masih ditoleransi oleh usaha supaya tidak mencapai kerugian. ${ }^{14}$

Analisis Pendapatan Usaha Laundry di Kecamatan Tampan Pekanbaru yang ditulis oleh Yesi Tri Sari. Penelitian ini mulai dilakukan pada bulan Juni 2012 sampai bulan Agustus pada tahun yang sama di kecamatan
Tampan pekanbaru. Populasi dalam penelitian ini adalah para pengusaha laundry di kecamatan Tampan Pekanbaru. Adapun sampel dalam penelitian ini adalah seluruh usaha laundry di kecamatan Tampan Pekanbaru yang berjumlah 25-unit usaha laundry. Teknik pengambilan data dilakukan dengan cara penyebaran angket dan wawancara langsung kepada pemilik usaha laundry. Dari hasil penelitian ini dapat disimpulkan: (1) rata-rata pendapatan usaha laundry mencapai Rp. 3.763.00,00 per bulan. (2) Laba yang diterima usaha landry mencapai Rp. 1.640.640,00 per bulan. (3) BEP yang ditetapkan usaha laundry agar tidak mengalami kerugian adalah sebesar 166 kgpakaian setiap harinya dengan tarif penjualan Rp. 1.619,00/kg. (4) pelanggan terbesar usaha laundry berasal dari kalangan mahasiswa atau anak kost yang tinggal di kecamatan Tampan dan sebagian kecilnya pelanggan laundry berasal dari penduduk setempat atau masyarakat di kecamatan Tampan. ${ }^{15}$

\section{DATA DAN METODOLOGI}

Teknik pengumpulan data yang dilakukan yaitu, Observasi atau pengamatan. Prosedur ini dilakukan untuk menemukan data dan informasi obyektif, sesuai dengan fenomena, serta apa adanya. Penulis mengamati operasional laundry amanah wash apakah dijalnkan sesuai dengan prosedur syariah.

Wawancara. Melalui prosedur ini, peneliti sebagai instrumen utama menggunakan instrumen tambahan berupa

\footnotetext{
${ }^{13}$ Rahmat Setiawan, Perancangan Jasa Layanan Baru di Djapa Laundry. Skripsi, Universitas Pasundan, 2016.

${ }^{14}$ Andriyanto Wibowo, Pengembangan laundry kiloan pada indie laundry dengan sistem outlet apartemen. Jurnal ilmiah universitas bakrie, vol 2, No.03 (2014)

${ }^{15}$ Yesi Tri Sari, Analisis Pendapatan Usaha Laundry di Kecamatan Tampan Pekanbaru. Diakses dari situs https://repository.unri.ac.id/xmlui/bitstream/handle/123456789/1619/JURNAL\%20YESI\%20TRI\%20SARI.pdf? sequence=1 pada tanggal 22 Desember 2017.
} 
buku catatan, dan tape recorder, dalam melakukan wawancara atau diskusi mendalam dengan informan. Yang terakhir Dokumentasi. Teknik dokumentasi dalam hal ini dilakukan dengan mengumpulkan berbagai catatan, laporan, atau dengan mengambil gambar atau foto-foto situasi yang situasi yang terkait dengan aktivitas amanah wash.

Metode analisis yang digunakan adalah analisis kualitatif dengan teknik komparasi dan interaktif. Teknik ini disebut juga teknik analisis komparatif konstan, yakni dengan membandingkan satu komponen dari data dengan komponen lainnya dari data tersebut, serta membandingkan temuan lain dan kesimpulan empiris dengan teori konvensional dan konsep-konsep lain yang relevan dengan focus penelitian ${ }^{16}$. Dilakukan dengan 4 tahapan yaitu:

1. Memperoleh pemahaman data sebagai suatu keseluruhan

2. Menyusun Deskripsi fenomena secara individual

3. Mengidentifikasikan tema-tema umum pada setiap deskripsi fenomena individual

4. Sintesis dari penjelasan tema-tema dalam setiap tema umum

Disamping teknik analisis komparasi juga digunakan teknik analisis interaktif, yakni teknik analisis data dengan proses reduksi data yang telah dikumpulkan, disajikan, disimpulkan dan diverivikasi dalam waktu yang hampir bersamaan ${ }^{17}$.

Langkah-langkah yang ditempuh dalam teknik interaktif adalah sebagai berikut ${ }^{18}$ :

1. Reduksi Data, Reduksi data adalah proses seleksi, penyederhanaan, pemfokusan, abstraksi dan transformasi data kasar yang muncul dari catatancatatan tertulis di lapangan. Proses ini berlangsung terus sepanjang pelaksanaan penelitian. Reduksi data dimulai sejak peneliti mengambil keputusan tentang kerangka kerja konseptual, permasalahan penelitian dan cara pengumpulan data yang dipakai. Pada saat pengumpulan data berlangsung, reduksi data dapat berupa ringkasan, mengkode, memusatkan tema, membuat batasan permasalahan, menulis memo. Proses reduksi ini terus berlangsung sesudah penelitian lapangan dan sampai laporan akhir penulisan selesai. ${ }^{19}$. Pada tahapan ini data diseleksi dan menyingkirkan data yang tidak penting, mengatur dan menyederhanakan dan memfokuskan ke arah pemahaman dan pemaknaan yang dibutuhkan.

2. Langkah selanjutnya yaitu sajian data, pada tahapan ini data disajikan, yaitu proses pengorganisasian informasi dan deskrispsi narasi dalam bentuk skema, gambar, dan atau menggunakan tabel. Yang kesemuanya didasarkan pada analisis isi (content analysis) dari setiap informasi yang berkaitan dengan minat konsumen.

\section{Hasil Dan Pembahasan}

\section{a. Profil Amanah wash syariah laundry}

Amanah wash syariah laundry merupakan salah satu usaha jasa pencucian pakaian yang terletak di jl. Jendral Ahmad Yani (depan asrama Hanura) Kota Langsa. Laundry ini berdiri pada 14 Januari 2017, asal

${ }^{16}$ Gamsir. Perilaku Muzakki Dalam Membayar Zakat Mal, Desertasi: Program Doktor Ilmu Manajemen Universitas Brawijaya, Malang: 2012, hal. 21.

${ }^{17}$ Ibid, hal. 22.

18 Ibid, hal. 22.

${ }^{19}$ Koentjaraningrat, Metode-metode Penelitian Masyarakat. Jakarta: Gramedia, 1986. hal. 269. 
mula pemilik memutuskan mendirikan usaha jasa di bidang pencucian yang berbasis syari'ah adalah karena melihat peluang di kota langsa, dan kegelisahan di dalam hatinya setelah melihat proses pencucian yang terjadi di laundry pada umumnya.

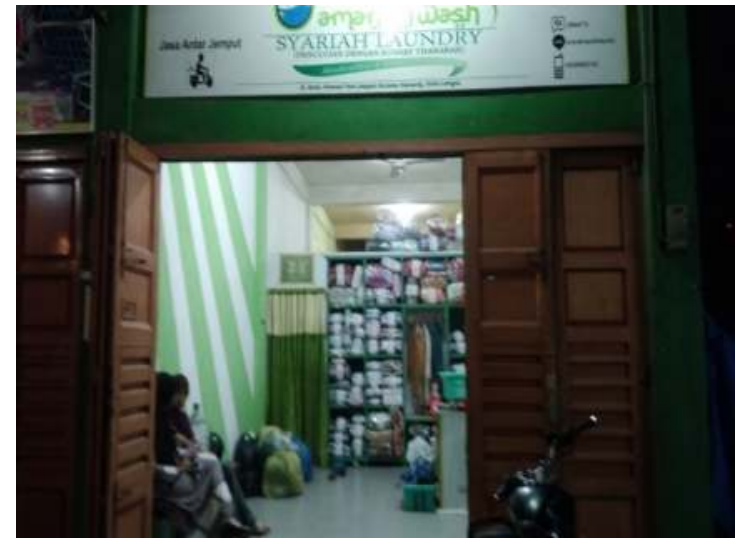

Gambar 4.1.

Toko amanah wash syariah laundry

Pencucian pakaian pada laundry secara umum terjadi dengan cara pencampuran seluruh pakaian pelanggan menjadi satu di dalam mesin pencuci. Padahal pakaian tersebut akan digunakan pada saat mengerjakan ibadah khususnya shalat, dimana salah satu syaratnya shalat adalah bersih pakaian dari hadast. Sedangkan pakaian hasil laundry belum tentu terpenuhi syarat sahnyanya shalat. Berbeda dengan konsep yang ditawarkan pada Amanah wash syariah laundry, menawarkan pencucian dengan konsep thaharah,

Thaharah mempunyai kedudukan yang penting serta pangkal pokok dari ibadah. Salah satu contoh konkret yang menunjukkan pentinnya thaharah adalah shalat seseorang tidak sah jika tidak ada thaharah. Hal ini sebagaimana sabda Rasulullah saw: "Allah tidak menerima shalat yang tidak dengan bersuci" (HR. Muslim)

Ajaran thaharah di dalam Islam mempunyai dua dimensi, yakni dimensi lahir dan dimensi batin. Allah SWT memberikan penganjaran kepada hambaNya melalui thaharah agar bersih dan suci, baik secara lahir maupun batin. ${ }^{20}$ Islam menuntut para pemeluknya untuk membersihkan hatinya dari syirik, dengki, dan iri hati. Allah SWT berfirman, “...sungguh, Allah menyukai orang yang tobat dan menyukai orang yang menyucikan diri." (QS. Al-Baqarah: 222)

Dari ajaran dimensi lahir, ajaran thaharah memberikan pengertian seorang muslim harus suci dari segala macam kotoran atau suci dari hadas. Bersuci dari kotoran dapat dilakukan dengan cara menghilangkan seluruh najis yang menempel dengan dengan menggunakan air yang bersih, baik dari pakaian, badan, maupun tempat shalat. Sedangkan, bersuci dari hadas dengan berwudhu, mandi, atau tayammum.

Adapun dimensi batin, seorang muslim hendaknya membersihkan jiwa dari dosa dan semua perbuatan maksiat, dengan cara bertobat secara sungguh-sungguh dari segala macam dosa dan maksiat. Di samping itu, ada upaya takziyatunnafs (membersihkan hati dari syirik, keragu-raguan, dengki, iri hati, tipu daya, sombong, ujub, riya', dan sum'ah). Upaya-upaya yang dimaksud dengan cara menanamkan keikhlasan, keyakinan, senang berbuat kebajikan, kelembutan, kejujuran, tawadhu' (rendah hati), serta menghendaki keridhaan mengerjakan amal-amal shaleh, seperti shalat.

Thaharah secara bahasa berarti nazhafah (kebersihan) atau bersih dari kotoran, baik bersifat hissiyah (nyata), seperti najis maupun yang bersifat maknawiyah, seperti aib atau perbuatan-perbuatan maksiat. Adapun secara syar'i, thaharah adalah menghilangkan hal-hal yang dapat menghalangi kotoran berupa hadas atau najis dengan menggunakan air atau selainnya. Atau

\footnotetext{
${ }^{20}$ Muhammad Anis sumaji, 125 Masalah Thaharah. 2008. (Surakarta: Tiga Serangkai). hal. 4.
} 
mengangkat hukum najis tersebut dengan tanah. Thaharah juga bermakna kebersihan dari sesuatu yang khusus di dalamnya dengan makna ta'abbudi kepada Allah SWT. Syariat Islam menghukumi thaharah sebagai hal yang wajib. Sebagaimana firman Allah:

"Dan bersihkanlah pakaianmu. (QS.

\section{Al-Muddatstsir :4)}

Penerapan thaharah di amanah wash syariah laundry dengan konsep thaharah yang mencakup dua hal, yaitu : thaharah zhahir dan batin. Thaharah zhahir sendiri adalah amanah wash menawarkan dapat menyucikan pakaian dari najis sesuai dengan ajaran Islam, yakni hilang warna, bau, dan rasanya. Kemudian thaharah batin disini terdapat pada batin pengelola dan pekerja di amanah wash, yang memiliki sifat-sifat amanah, siddiq, tabligh. Amanah dalam arti pihak amanah wash melayani pelanggan sesuai dengan permintaan pelanggan, seperti seorang pelanggan tidak ingin memakai pewangi/parfum pada pakaiannya karena berkeyakinan bahwa alkohol tidak dapat digunakan untuk ibadah shalat. Sifat siddiq atau jujur dalam bekerja dan tabligh adalah menyampaikan jika sesuatu yang tidak diingankan terjadi dari barang pelanggan, seperti hilang, luntur, dan cacat.

Pelanggan yang menggunakan jasanya selama enam bulan telah mencapai 250 orang. Hal ini menandakan adanya antusias dari masyarakat kota Langsa terhadap produk usaha laundry syariah ini terbilang sangat baik. Pelanggan amanah wash sebagian besar mengetahui keberadaan laundry syariah ini dari rekomendasi temannya. Ada juga seorang pelanggan yang memang sengaja mencari jasa laundry yang berbasis syariah, hal ini dikarenakan istrinya yang baru saja melahirkan mengkhawatirkan kesucian pakaiannya jika diberikan ke jasa laundry biasa. ${ }^{21}$

Amanah wash syariah laundry pada awal berdiri usaha ini hanya memiliki satu orang karyawan yang mengerjakan semua pekerjaan hingga selesai, mulai dari pemilahan baju, pencucian dan terakhir penyetrikaan. Memasuki bulan kelima jumlah karyawan yang bekerja di amanah wash syariah laundry meningkat, hingga saat ini telah mencapai 7 orang karyawan.

\section{b. Produk-produk Amanah wash syariah laundry}

Amanah wash syariah laundry memiliki beberapa produk yang ditawarkan kepada pelanggang, yaitu :

Tabel 1. Produk Amanah Wash Syariah Laundry

\begin{tabular}{lll}
\hline No & \multicolumn{1}{c}{ Jenis Laundry } & \multicolumn{1}{c}{ Harga } \\
\hline 1 & $\begin{array}{l}\text { Paket bulanan } \\
\text { keluarga }\end{array}$ & Rp. 250.000/ bulan \\
2 & $\begin{array}{l}\text { Paket bulanan } \\
\text { personal }\end{array}$ & Rp. $100.000 /$ bulan \\
3 & Dry clean & $\begin{array}{l}\text { Mulai } \\
\text { Rp. } 15.000 / \text { potong }\end{array}$ \\
4 & Express service & Rp. $12.000 / \mathrm{kg}$ \\
5 & Cuci bedcover & Rp. $6000 / \mathrm{kg}$ \\
6 & Paket bulanan & Rp. $150.000 /$ bulan \\
& hemat & Rp. $6000 / \mathrm{kg}$ \\
7 & Cuci kiloan & Rp. $3500 / \mathrm{kg}$ \\
8 & Setrika saja/cuci & \\
& kering & Rp. $100.000 / 30 \mathrm{~kg}$ \\
9 & Paket setrika & Rp. $30.000 / \mathrm{pc}$ \\
10 & Helm & Rp. $8.000 / \mathrm{kg}$ \\
11 & Gorden & mulai dari \\
12 & Boneka & Rp. $10.000 / \mathrm{pc}$ \\
& & mulai dari \\
13 & Ambal & Rp.35.000/pc \\
\hline
\end{tabular}

Sumber : Amanah Wash Syariah Laundry, 2017

Dari tabel di atas menunjukkan bahwa jenis produk yang ditawarkan dan ketetapan

${ }^{21}$ Wawancara dengan owner amanah wash, Ibu Masyitah. Pada tanggal 29 jam 21.10 WIB. 
harga yang ditawarkan juga berbeda. Mulai dari paket bulanan untuk keluarga satu bulan $50 \mathrm{~kg}$, dimana jika dalam 1 bulan member tidak mencukupi $50 \mathrm{~kg}$. Maka bulan selanjutnya masih berlaku paket bulan lalu sampai terpenuhi $50 \mathrm{~kg}$. Berbeda dengan laundry paket personal perbulan yang dihargai Rp. 100.000/bulan.

Produk selanjutnya yang ditawarkan oleh amanah wash syariah laundry adalah produk yang mudah dry clean dengan bandrol Rp.15.000/ potong, dimana dry clean sendiri adalah produk yang ditawarkan untuk mencuci pakaian yang berbahan lembut atau jas formal milik keluarga. Pelanggan yang menggunakan produk ini menjaga agar pakaian yang ia miliki tidak salah dalam pencucian.

Kemudian produk selanjutnya adalah express service, dimana pelayanan mencuci pakaian dalam waktu yang sangat singkat lebih kurang 2 jam, atau biasa setengah hari. Pelanggan yang menggunakan produk ini biasanya mereka yang mempunyai kegiatan yang sangat padat, sehingga tidak mempunyai waktu untuk mencuci atau mengantar cucian dalam jangka waktu panjang. Bisa dikatakan juga pelanggan yang menggunakan produk ini dalam keadaan yang mendesak, sehingga membutuhkan pelayanan yang serba cepat.

Produk selanjutnya adalah bedcover dengan harga Rp. 6000/kg, dan cuci kiloan dengan Rp. 6000/kg, kemudian Setrika saja dengan harga Rp. 3500/kg. pelanggan yang menggunakan produk setrika biasanya mereka yang memang pada dasarnya tidak telaten dalam hal menyetrika pakaian, karena ada beberapa orang lebih menyukai mencuci saja, hal ini dikarenakan saat ini setiap rumah tangga mayoritas telah memiliki mesin cuci, sehingga tidak lagi dengan cara manual untuk mencuci pakaian. Dengan adanya produk ini memudahkan bagi mereka yang memiliki kesibukan.
Kemudian, produk yang ditawarkan pihak amanah wash syariah laundry adalah paket bulanan hemat dengan harga $\mathrm{Rp}$. 100.000 / bulan, dan paket setrika seharga $\mathrm{Rp}$. 150.000 / $30 \mathrm{~kg}$. Dengan membeli paket ini seorang pelanggan akan lebih menghemat anggaran, karena produk-produk paket lebh murah dibandingkan dengan produk yang perkiloan.

Selanjutnya produk yang tak kalah dengan produk lain adalah produk pencucian boneka dan ambal, dengan harga sesuai besar kecil boneka dengan harga dimulai dari Rp.10.000 / pc, dan lebar tidaknya sebuah ambal dihargai mulai Rp.35.000 / pc. Pelanggan yang tidak ingin repot dengan pencucian ambal dan boneka yang relatif tebal dan lama, sehingga mereka memilih untuk menggunakan produk yang ditawarkan oleh amanah wash syariah laundry.

Produk terakhir adalah pencucian helm dan gorden dengan harga helm Rp. 30.000 / pc, dan harga gorden Rp. 8.000/ kg. pencucian helm biasanya adalah helm yang tergolong dengan kualitas bagus sehingga pemilik helm dalam hal memelihara helmnya dengan baik salah satunya dengan membersihkannya. Kemudian pelanggan yang menggunakan produk gorden dikarenakan pencucian gorden sendiri yang terlalu lebar dan panjang, dengan adanya produk pencucian gorden memudahkan pelanggan dalam membersihkan/mencuci gordennya yang telah tdiak bersih lagi.

\section{c. Struktur Organisasi dan Job description Amanah wash syariah laundry}

Amanah wash syariah laundry tidak hanya menyediakan fasilitas cuci-setrika pakaian saja, tetapi juga menyediakan fasilitas cuci dan setrika non pakaian (tidak dihitung berdasarkan hitungan kilogram).

1. Jasa yang dihasilkan 
a) Jasa Cuci dan Pengeringan Menyediakan layanan jasa mencuci dan mengeringkan pakaian. Dengan metode-metode pencucian yang baik.

b) Jasa Cuci, Pengeringan dan Setrika

Menyediakan layanan jasa mencuci, mengeringkan dan menyetrika. Untuk jasa setrika, amanah wash syariah laundry memberikan pelayanan yang terbaik.

c) Layanan Antar Jemput

d) Amanah wash syariah laundry juga menyedikan jasa layanan antar jemput, sehingga dapat memudahkan konsumennya.

2. Keunggulan Jasa Amanah wash syariah lauundry

Beberapa keunggulan yang dimiliki oleh Amanah wash syariah laundry adalah :

a) Harga terjangkau

b) Sesuai syariah Islam

c) Pewangi bisa sesuai selera

d) Cucian tidak dicampur dengan orang lain.

e) Kontrol terhadap kepemilikan baju yang baik, sehingga tidak ada baju yang hilang.

f) Layanan antar jemput

g) Ada diskon lebih hemat jika menjadi member

Tabel 2. Struktur Organisasi Amanah Wash Syariah Laundry

\begin{tabular}{llc}
\hline No & Job Description & Jml. Karyawan \\
\hline 1 & Manager & 1 orang \\
2 & Receptionist & 2 orang \\
3 & Petugas Pencuci & 2 orang \\
4 & Petugas Penggosok & 2 orang \\
\hline \multicolumn{2}{c}{ Sumber : Amanah wash Syariah Laundry, 2017 }
\end{tabular}

Dari tabel tersebut diketahui bahwa jumlah seluruh karyawan di amanah wash syariah laundry berjumlah 7 orang. Dimana 1 orang sebagai manager mencakup owner amanah wash laundry yaitu, ibu masyitah, S.Pd. Kemudian 2 orang receptionist yang bekerja sebagai penerima jika ada pelanggan yang mengantar laundry atau mengambil laundry. Yang bertugas dan mengetahui jika ada kehilangan pakaian pelanggan adalah receptionist, karena dimulai dari pakaian yang diantar akan dihitung dan dipilah mana yang bisa digabung dalam pencucian (tidak luntur) dan mana yang harus dipisah. Sehingga jika ada pakaian yang hilang pihak receptionist lah yang mengetahui, waktu bekerjanya berupa shift, yaitu shift pagi sampai sore $\mathrm{n}$ shift sore sampai malam.

Kemudian terdapat 2 orang pencuci pakaian yang dalam proses pencucian harus memulai dengan cara manual/tangan, sampai hilang najis yang melekat di pakaian, kemudian pakaian yang tidak ada najisnya lagi dimasukkan ke dalam mesin cuci, selanjutnya membilasnya dengan mendatangkan air ke pakaian bukan sebaliknya. Kemudian pakaian yang tidak ada najisnya. Karyawan terakhir adalah karyawan penyetrika jika telah kering pakaian yang dicuci.

\section{d. Dampak Label Syariah Terhadap Pendapatan}

Tabel 3. Pendapatan Amanah wash Syariah Laundry

\begin{tabular}{lllr}
\hline No & Bulan & \multicolumn{2}{c}{ Pendapatan } \\
\hline 1. & Januari & Rp. & $1.250 .000,-$ \\
2. & Februari & Rp. & $8.082 .700,-$ \\
3. & Maret & Rp. & $8.444 .268,-$ \\
4. & April & Rp. & $10.454 .500,-$ \\
5. & Mai & Rp. & $8.434 .700,-$ \\
6. & Juni & Rp. & $9.406 .625 .5,-$ \\
7. & Juli & Rp. & $12.901 .600,-$ \\
\hline
\end{tabular}




\begin{tabular}{clcr} 
8. & Agustus & Rp. & $11.843 .698 .5,-$ \\
9. & September & Rp. & $6.515 .200,-$ \\
10. & Oktober & Rp. & $683.232,-$ \\
\hline mber: Amanah Wash Syariah Laundry, 2017
\end{tabular}

Berdasarkan tabel di atas menunjukkan bahwa pendapatan Amanah wash Syariah laundry fluktuatif. Pendapatan paling rendah pada bulan Oktober yaitu sebesar Rp. 683.232,- dan pendapatan tertinggi terjadi pada bulan Juli yaitu sebesar Rp. 12.901.600,Sedangkan pada bulan Januari ke Februari, mengalami kenaikan yang signifikan dari pendapatan Rp. 1.250.000,- menjadi Rp. 8.082.700,- Hal ini dikarenakan sudah mulai tersebar keberadaan amanah wash syariah laundry, pemasaran yang dilakukan oleh pihak amanah wash syariah laundry salah satunya dengan cara mulut ke mulut, dan teman ke teman.

Pendapatan dari maret ke april mengalami kenaikan sebesar $4.47 \%$, hal ini dikarenakan masih hanya orang-orang yang sama yang menjadi pelanggan amanah wash syariah laundry dan pelanggan mengajak teman atau saudara dari pelanggan untuk menggunakan jasa amanah wash syariah laundry. Dalam waktu 1 bulan kenaikan ini termasuk besar.

Amanah laundry menawarkan sistem pencucian pakaian berdasarkan ajaran Islam dengan harapan agar masyarakat Kota Langsa berbondong-bondong menggunakan jasanya. Hal ini dikarenakan mayoritas penduduk Kota Langsa beragama muslim, sehingga pakaian yang dipakai ketika beribadah tidak hanya bersih secara zhahir namun juga suci dari hadast. Sistem yang digunakan pada Amanah laundry adalah pencucian secara manual dengan menggunakan tangan, sehingga kecepatan pelayanan juga terhambat. Jika pada laundry lain hanya memakan waktu 3 hari, berbeda dengan amanah laundry yang memakan sampai 4 hari. Sehingga tidak sedikit pelanggan yang mengeluh tentang keterlambatan layanan yang diberikan oleh Amanah laundry ini.

Dalam mengatasi masalah ini dari awal penerimaan pakaian kotor pelanggan, karyawan Amanah laundry memberi tahu terlebih dahulu segala ketentuan proses pencucian, sehingga tidak ada pihak yang merasa dirugikan nantinya. Sebagai contoh, ada beberapa pelanggan yang memberikan pakaian dinas di hari Jumat dengan harapan pada malam senin atau Minggu malam dapat diambil, namun sebelumnya pihak Amanah laundry memberikan penjelasan apa yang akan terjadi ke depan, hal ini juga berjalan lancar atas dukungan cuaca yang baik pada siang hari.

Beberapa pelanggan yang menggunakan jasa Amanah laundry tidak melihat bagaimana proses pencucian yang ditawarkan, namun melihat hasil yang terlihat dari layanan Amanah laundry yang sebagian besar mengatakan hasilnya adalah bersih. Sehingga ada beberapa pelanggan yang memakai jasanya walau jarak yang ditempuh jauh, serperti dari Alue Dua dan Sidodadi. Mereka melewati beberapa laundry hanya untuk ke Amanah laundry.

Ada pilihan yang ditawarkan Amanah laundry kepada pelanggan agar lebih hemat dalam memakai jasa pencucian di Amanah laundry, yaitu dengan menjadi member Amanah laundry. Jika tanpa menjadi member, per kilo dihitung Rp.7000, maka dengan menjadi member setiap anggota member akan mendapat potongan sebsar Rp.1000 per kilo. Hingga saat ini yang telah menjadi member sebanyak 25 orang dari 250 pelanggan.

Ada beberapa produk yang ditawarkan Amanah laundry, diantaranya: paket familiy, mini family, personal, dry clean, hemat personal, super hemat, cuci kiloan, express service, cuci bedcover, cuci boneka, gorden dan ambal. Dari beberapa produk tersebut, 
produk yang paling sering dibeli pelanggan adalah jasa cuci kiloan dan paket family. Paket family pada Amanah laundry berbeda dengan paket keluarga di laundry lainnya. Jika di laundry lain paket keluarga $50 \mathrm{~kg}$ berlaku hanya dalam satu bulan saja, sedangkan di amanah laundry berlaku $50 \mathrm{~kg}$ walaupun sudah lewat satu bulan.

Dalam menjalankan usaha jasa Amanah laundry, hubungan sosial tidak terlalu berpengaruh terhadap peningkatan pelanggan pengguna jasa Amanah laundry. Sebagian besar pelanggan adalah orang yang tidak ada pertalian sosial sebelumnya dengan pemilik atau karyawan Amanah laundry. Dan pelanggan yang menggunakan jasa Amanah laundry lebih banyak non member setiap harinya, sebagai contoh pada hari Rabu pelanggan member menggunakan jasa laundry sebanyak $3.7 \mathrm{~kg}$, dan non member sebanyak $51.1 \mathrm{~kg}$.

Selama tujuh bulan beroperasi pelanggan Amanah laundry mengalami peningkatan. Awal beroperasi pelanggan hanya orang-orang yang berdomisili di sekitar Amanah laundry saja, namun lambat laun meluas ke pelanggan yang berdomisili lebih jauh. Peningkatan pelanggan paling tinggi terjadi ketika bulan Ramadhan, antara alasannya dikarenakan pada bulan puasa para pelanggan ingin fokus untuk beribadah sehingga menggunakan jasa Amanah laundry. Pada saat Ramadhan jumlah pakaian kotor pelanggan yang dititip bisa mencapai $151 \mathrm{~kg}$ per hari. Setelah Ramadhan berlalu, pelanggan pun mulai menurun tak sebanyak ketika bulan Ramadhan.

Pada dasarnya semakin tinggi pendapatan, pengeluaran juga semakin tinggi. Seperti itu juga yang terjadi pada Amanah laundry. Semakin besar minat pelanggan, pengeluaran belanja juga semakin tinggi. Anggaran belanja diantaranya dialokasikan untuk membayar gaji karyawan sebanyak 7 orang yang awalnya hanya 1 orang, untuk membuat sumur bor agar lebih menghemat pengeluaran mengingat semakin mahalnya tagihan PDAM. Selain itu Amanah laundry tidak mengurangi bahan-bahan dasar yang digunakan untuk mencuci seperti pewangi, cairan pencuci, cairan penghilang noda dan lain-lain.

Secara umum hanya sebagian kecil saja pelanggan Amanah laundry yang memutuskan untuk menjadi pelanggan Amanah laundry berdasarkan adanya label syari'ah yang dicantumkan atau yang ditawarkan oleh pihak owner. Sedangkan sebagian besarnya memutuskan menjadi pelanggan adalah karena hasil cucian oleh Amanah laundry memuaskan pelanggan, yaitu bersih dan wangi. Dengan demikian, label syariah tidak memiliki dampak terhadap peningkatan pendapatan pada Amanah laundry.

Promosi yang dilakukan oleh amanah wash syariah laundry selama ini menggunakan personal selling berupa kenalan pihak owner dengan lingkungan sekitarnya, baik di lingkungan ia kerja ataupun lingkungan tempat tinggalnya. Kemudian promosi bersifat public relation dan beberapa media cetak berupa brosur untuk mendukung kegiatan pemasaran personal selling.

\section{E. KESIMPULAN}

Dari pembahasan di atas maka penulis dapat menyimpulkan hasil penelitian sebagai berikut:

1. Pengaruh label syariah terhadap pendapatan amanah wash syariah laundry tidak berpengaruh secara signifikan karena beberapa pelanggan menggunakan jasa laundry berdasarkan logis, lokasi, dan lainlain. hanya beberapa yang menggunakan jasa laundry berdasarkan religiusitas. 
2. Aplikasi thaharah pada pencucian pakaian di amanah wash syariah laundry sudah sesuai, hal ini didapati pencuci memisahkan pakaian yang bernajis dengan yang tidak, dan menghilangkan ciri-ciri najis.

\section{DAFTAR PUSTAKA}

A.B. Susanto dan Himawan Wijanarko, Membangun Merek Unggul dan Organisasi Pendukungnya, (Jakarta: Penerbit Quantum Bisnis \& Manajemen, 2004)

Abdurrahman, Inilah Syariah Islam. Jakarta: P ustaka paji emas, 1991.

Afandy Tjiptono, Strategi Pemasaran. Yogyakarta: CV Andi Offset, 2001.

Arif Rahman, Strategi Dahsyat Marketing Mix for Small Business: Cara Jitu Merontokkan Pesaing, (Jakarta: TransMedia, 2010)

Brilyan Rahmat Sukmono, Pengaruh Label "Syariah" Pada Lembaga Perbankan Terhadap Jumlah Nasabah BNI Syariah Cabang Jakarta Selatan. Skripsi. UIN Syarif Hidayatullah.

David A. Aaker, Managing Brand Equity: Capitalising on The Value of Brand Name (New York: The Free Press, 1991)

Ferdianand A, structural equation modelling dalam penelitian manajemen: aplikasi model-model rumit dalam penelitian untuk tesis magister dan disertasi doktor. Semarang: BPUNDIP, 2002.

Gamsir. Perilaku Muzakki Dalam Membayar Zakat Mal, Desertasi: Program Doktor Ilmu Manajemen Universitas Brawijaya, Malang: 2012.

Habib Nazir dan Muhammad Hasanuddin, 2008. Ensiklopedi. Hal. 245
Hermawan Kartajaya, The Official MIM Academy Coursebook: Brand Operation, (Jakarta: Esensi Erlangga Group, 2010)

Husein Umar, Riset Pemasaran dan Perilaku Konsumen (Jakarta: PT Gramedia Pustaka Utama, 2000)

Kasmir dan Jakfar, Studi Kelayakan Bisnis (Jakarta: Kencana, 2008)

Koentjaraningrat, Metode-metode Penelitian Masyarakat. Jakarta: Gramedia, 1986.

Kotler, dkk. Manajemen Pemasaran: Analisi, Perencanaan, Implementasi, dan Pengendalian (terjemahan). Jakarta: Erlangga, 2003.

Kuat Ismanto, Manajemen Syariah, (Yogyakarta, Pustaka Pelajar, 2009)

Lamb, Hair, Mc Daniel, Manajemen Pemasaran (Jakarta: Salemba Empat, 2001)

M. Nur Rianto Al-Arif, Dasar-dasar Pemasaran Bank Syariah (Bandung: Alfabet, 2010)

Maya Anggraeini, Pengaruh Persepsi Label Halal, Citra Merek (Brand Image), dan word of mouth (WOM) Terhadap Minat Beli Ulang Produk (Studi Kasus Pada Restoran Solaria Ambarukmo Plaza Yogyakarta). Skripsi Universitas Negeri Yogyakarta, 2016.

Muhammad Syakir Sula dan Hermawan Kertajaya, Syariah Marketing (Jakarta: Mizan, 2005)

Muhammad, 2004. Etika bisnis islam, (akademi manajemen jilid 2. Hal. 523 perusahaan YKPN, Yogyakarta)

Muhammad, Etika Bisnis Islam, (Yogyakarta, Akademi Perusahaan YKPN, 2011)

Nurul Huda dan Muchlisin, Pengaruh Label Halal Pada Makanan Terhadap Konsumsi Mahasiswa Fakultas Agama Islam Universitas Muhammadiyah 
surakarta. Suhuf, Vol.26, No.1, Mei 2014.

Philip Kotler dan Kevin Lane Keller, Manajemen Pemasaran, Alih Bahasa Benyamin Molan (Jakarta; indeks, 2007)

Rosady Ruslan, Metode Penelitian Public Relations dan Komunikasi, Cet. IV, Edisi, I Jakarta: PT. Raja Grafindo Persada, 2008.

Saiful Bahri, Faktor-Faktor Yang Mendasari Konsumen Dalam Memilih Hotel Syariah Walisongo. Skripsi, UIN Sunan Ampel, 2015.

Sriwijaya Post, Stategi Pemasaran dalam Islam, diakses pada 15 Desember 2017 dari http://palembang.tribunnews.com

Sugiyono, Metode Penelitian Kuantitatif, Kualitatif dan $R \& D$. Jakarta: Alfabeta, 2011.
Sutopo, H.B. Metodologi Penelitian Kualitatif. Surakarta: UNS Press, 2006.

Thorik Gunara dan Utus Hardiono S, Marketing Muhammad saw (Bandung: Madania Prima, 2007)

Ujang Sumarwan, Perilaku Konsumen, Teori dan Penerapannya dalam Pemasaran. Bogor: Gahlia, 2011.

Wahyu budi utami, Pengaruh label halal terhadap keputusan membeli (survei pada pembeli produk kosmetik wardah di outlet wardah griya muslim an-nisa yogyakarta). Skripsi UIN Sunan Kalijaga, 2013.

Widyarini, Pemanfaatan Peluang Bisnis Laundry Syariah. Jurnal Ekonomi dan Bisnis Islam, Vol. XI, No. 1, Desember 2015. 